concentrations and alkaline phosphatase activity remain normal. Our policy is to give vegetarian Asians with osteomalacia 3000 units $(75 \mu \mathrm{g})$ of vitamin $\mathrm{D}_{2}$ syrup once a month for life.

We thank Miss Marion Amos for typing the manuscript and Tina Stallion for preparing the figure.
1 McPaul JJ, McIntosh DA, Hammond WS, et al. Autonomous secondary renal parathyroid hyperplasia. N Engl f Med 1964;271:1342-5.

2 Davies DR, Dent CE, Willcox A. Hyperparathyroidism and steatorrhoea. BrMed F 1956;ii:1133-7.

3 Dandona P, Mohiuddin J, Weerakoon JW, Freedman DB, Fonseca V, Healey T. Persistence of parathyroid hypersecretion and vitamin D treat ment in Asian vegetarians. F Clin Endocrinol Metab 1984;59:535-7.

(Accepted 10 May 1989)

\title{
Use of endoscopy in patients with dyspepsia
}

Dino Vaira, John Holton, John Osborn, John Dowsett, Ian McNeil, Adrian Hatfield

Department of

Gastroenterology and

Microbiology, Middlesex

Hospital, London

WIN 8AA

Dino Vaira, $M D$, research

assistant

John Holton, MRCPATH, senior lecturer

John Dowsett, MRACP, research fellow

Ian McNeil, MRCP, consultant

Adrian Hatfield, FRCP, consultant

\section{Centre for Population}

Studies, London School of

Hygiene and Tropical

Medicine, London

WC1E 6AZ

John Osborn, PHD, senior

lecturer

Correspondence to:

Dr Vaira.

BrMed f 1989;299:237
Dyspepsia may be an early symptom of a serious illness, such as peptic ulceration, cholelithiasis, or gastric carcinoma. Many patients with dyspepsia are examined by upper gastrointestinal endoscopy, but organic lesions are not found in up to one third. There is little evidence to show that endoscopy is helpful,

on histological examination were compared with the $t$ test after logarithmic transformation.

The most common symptoms experienced by the patients were postprandial bloating with nausea (68), epigastric pain (18), and halitosis and heartburn (21). Sixty two of the patients showed histological evidence of active on chronic gastritis; all of these also had $C$ pylori on microscopy, and $C$ pylori was cultured in 51 cases. The remaining 45 patients had normal histological features without evidence of gastritis or $C$ pylori. Normal endoscopic findings were obtained in 63 of the 107 patients, while 39 were found to have patchy erythema and five superficial erosions. The table shows the sensitivity, specificity, and positive and negative predictive values of endoscopy and the other

Sensitivity, specificity, and positive and negative predictive values of various investigations used to diagnose active on chronic gastritis associated with Campylobacter pylori in 107 patients

\begin{tabular}{|c|c|c|c|c|c|c|c|c|c|c|}
\hline & \multicolumn{2}{|c|}{ Endoscopy } & \multicolumn{2}{|c|}{ Culture } & \multicolumn{2}{|c|}{ Rapid urease test } & \multicolumn{2}{|c|}{ IgG $>504^{\star}$} & \multicolumn{2}{|c|}{$\operatorname{IgA}>205^{\star}$} \\
\hline & Positive & Negative & Positive & Negative & Positive & Negative & Yes & No & Yes & No \\
\hline $\begin{array}{l}\text { Histological diagnosis of gastri } \\
\text { Positive } \\
\text { Negative }\end{array}$ & $\begin{array}{l}23 \\
21\end{array}$ & $\begin{array}{l}39 \\
24\end{array}$ & 51 & $\begin{array}{l}11 \\
45\end{array}$ & 58 & $\begin{array}{r}4 \\
45\end{array}$ & $\begin{array}{r}56 \\
2\end{array}$ & $\begin{array}{r}6 \\
43\end{array}$ & $\begin{array}{l}35 \\
10\end{array}$ & $\begin{array}{l}27 \\
35\end{array}$ \\
\hline $\begin{array}{l}\text { Sensitivity (\%) } \\
\text { Specificity (\%) } \\
\text { Positive predictive value }(\%) \\
\text { Negative predictive value }(\%)\end{array}$ & \multicolumn{2}{|c|}{$\begin{array}{l}37 \\
53 \\
52 \\
38\end{array}$} & & & & & & & & \\
\hline
\end{tabular}

^Optical density at $450 \mathrm{~nm}$.

though a histological examination often shows the presence of gastritis.

A strong association between the presence of Campylobacter pylori in the gastric mucosa and histologically confirmed type B gastritis is well recognised. ${ }^{1}$ It is not clear how commonly gastritis associated with $C$ pylori occurs in dyspepsia without ulceration and whether the presence of $C$ pylori results in different symptoms. We therefore carried out a prospective study of patients with dyspepsia to try to determine this. We also compared the sensitivity and specificity of endoscopic examination with those of histological examination, rapid urease tests, ${ }^{2}$ serological tests, and culture to determine whether endoscopy and antral biopsies are useful.

\section{Patients, methods, and results}

We studied 107 consecutive patients with dyspeptic symptoms, whose endoscopy showed either no abnormality or minor inflammatory features in the antrum (usually patchy erythema). One of us (DV) asked the patients whether they had epigastric pain, nausea, heartburn, halitosis, and postprandial bloating. At endoscopy four antral biopsy specimens were taken from each patient for histological examination. Rapid urease activity was tested, samples were cultured, and serum immunoglobulin concentrations were measured. ${ }^{13}$ Histological evidence of $C$ pylori was taken as confirmation of the presence of the organism. The sensitivity, specificity, and positive and negative predictive values were calculated for each test compared with histological examination. In addition concentrations in the patients positive and negative for $C$ pylori investigations assessed when compared with the histological findings. IgG concentrations had a high sensitivity and specificity.

\section{Comment}

We found that $58 \%$ of patients with dyspepsia without ulceration had gastritis on histological examination even though in many of them the mucosa appeared normal at endoscopy. In all cases the gastritis was associated with $C$ pylori. The main symptom experienced by the patients was postprandial bloating, which was present in $73 \%(45 / 62)$ of those with gastritis and $51 \%(23 / 45)$ of those without gastritis. Serological testing for $C$ pylori is useful in screening a population at risk, ${ }^{4}$ to monitor the response to treatment, ${ }^{5}$ and perhaps to investigate patients with dyspepsia before endoscopy. Our data showed that endoscopy had a lower sensitivity and specificity than all the other tests used. We conclude that endoscopy is unhelpful in patients with dyspepsia if endoscopic biopsy specimens are not taken routinely.

1 Vaira D, Holton J, Falzon M, et al. Investigation of Campylobacter pylor associated gastritis by histology culture, urease tests, brushings and antibody levels. Italian foumal of Gastroenterology 1988;20:299-304.

2 Vaira D, Holton J, Cairns S, et al. Urease tests for Campylobacter pylori: care in interpretation. F Clin Pathol 1988;41:812-3.

3 Oderda G, Vaira D, Holton J, Dowsett JF, Ansaldi N. Serum pepsinogen I an IgG antibody to Campylobacter pylori in non specific abdominal pain in childhood. Gut (in press)

4 Vaira D, D'Anastasio C, Holton J, et al. Campylobacter pylori in abattoir workers: is it zoonosis? Lancet 1988;ii:725-6.

5 Oderda G, Vaira D, Holton J, et al. Amoxycillin plus tinidazole for Campylobacter pylori gastritis in children: assessment by serum IgG antibody, pepsinogen I, and gastrin levels. Lancet 1989;i:690-2.

(Accepted 19 April 1989) 